\title{
Black Dwarf Honey Bee Apis andreniformis Smith, 1858 (Insecta: Hymenoptera: Apidae) ${ }^{1}$
}

\author{
Mary Nordgulen, Brynn Johnson, and Cameron Jack ${ }^{2}$
}

\section{Introduction}

The Featured Creatures collection provides in-depth profiles of insects, nematodes, arachnids and other organisms relevant to Florida. These profiles are intended for the use of interested laypersons with some knowledge of biology as well as academic audiences.

The black dwarf honey bee, Apis andreniformis Smith 1858 (Figure 1), is a small dark honey bee found in Southeast Asia. It is one of two honey bee species in the subgenus Micrapis, which includes its sister, the red dwarf honey bee, Apis florea. These are thought to be the most primitive honey bee species, demonstrated by their small colonies and open-nest construction (Raffiudin and Crozier 2007). The single comb nest of Apis andreniformis is smaller than that of Apis florea. It has a mid-rib both above and below the supporting twig of the nest, giving it a crest-like appearance (Rinderer et al. 1996).

Previously considered a subspecies of Apis florea, morphological and behavioral differences confirmed Apis andreniformis as a distinct and separate species in the late 1900s (Wongsiri et al. 1990; Wu and Kuang 1986, 1987; Rinderer et al. 1993). Apis andreniformis is less abundant with a smaller geographical footprint than Apis florea and may need to be assessed for conservation status (Rattanawannee et al. 2007).

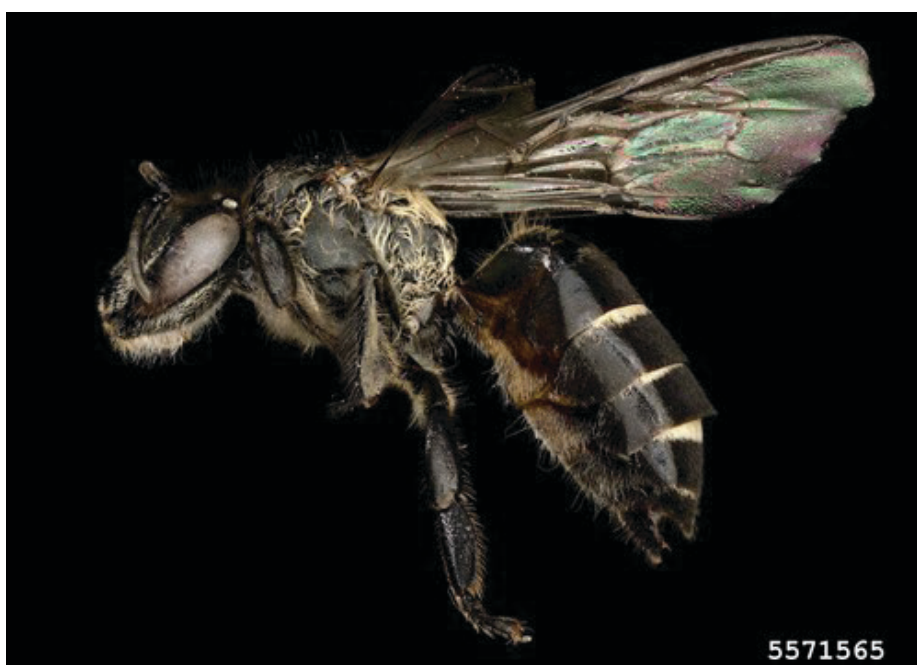

Figure 1. View from the side of an adult female Apis andreniformis Smith.

Credits: Tevan Brady, Exotic Bee ID, USDA APHIS PPQ, Bugwood.org

\section{Synonymy}

Patellapis andreniformis (Friese 1925) (ITIS 2020).

\section{Distribution}

Apis andreniformis is distributed throughout tropical and subtropical Southeast Asia (Figure 2). This bee is found as far east as the Philippines, south as Sundaland, and north as the eastern foothills of the Himalayas. Geographical distribution includes India, Southeast China, Myanmar, Laos, Thailand, Vietnam, Malaysia, and Indonesia (Gupta

1. This document is EENY-1317, one of a series of the Entomology and Nematology Department, UF/IFAS Extension. Original publication date November 2020. Visit the EDIS website at https://edis.ifas.ufl.edu for the currently supported version of this publication. This document is also available on the Featured Creatures website at http://entomology.ifas.ufl.edu/creatures.

2. Mary Nordgulen; Brynn Johnson; and Cameron Jack, Entomology and Nematology Department, UF/IFAS Extension, Gainesville, FL 32611.

The Institute of Food and Agricultural Sciences (IFAS) is an Equal Opportunity Institution authorized to provide research, educational information and other services only to individuals and institutions that function with non-discrimination with respect to race, creed, color, religion, age, disability, sex, sexual orientation, marital status, national origin, political opinions or affiliations. For more information on obtaining other UF/IFAS Extension publications, contact your county's UF/IFAS Extension office. U.S. Department of Agriculture, UF/IFAS Extension Service, University of Florida, IFAS, Florida A \& M University Cooperative Extension Program, and Boards of County Commissioners Cooperating. Nick T. Place, dean for UF/IFAS Extension. 
et al. 2014). Apis adreniformis is not found in cool, dry climates within this region and is considered a lowland species, with their nests occurring at less than $1000 \mathrm{~m}$ elevations (Hepburn and Radloff 2011).

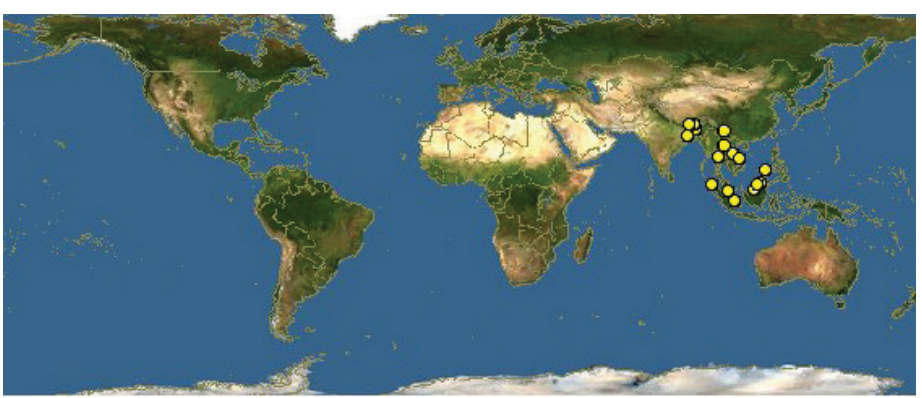

Figure 2. Global distribution of Apis andreniformis Smith. Credits: Discover Life (https://www.discoverlife.org/ $\mathrm{mp} / 20 \mathrm{~m}$ ?kind=Apis+andreniformis)

\section{Description}

Apis andreniformis is the smallest and darkest honey bee species. It is approximately 6.5 to $10 \mathrm{~mm}$ (.25 to .39 inches) in length and primarily black in color. It is frequently misidentified as Apis florea, but can be discerned by morphological features, specifically male (drone) genitalia, and color. Apis andreniformis female worker bees have a yellow scutellum (dorsal rear portion of the thorax) (Figure 3) in contrast to the black scutellum of Apis florea (Rinderer et al. 1995, Rattanawannee et al. 2007). The hind legs of Apis andreniformis female worker bees also have black hairs (Figure 4) in comparison to Apis florea, which are white (Smith 1858).

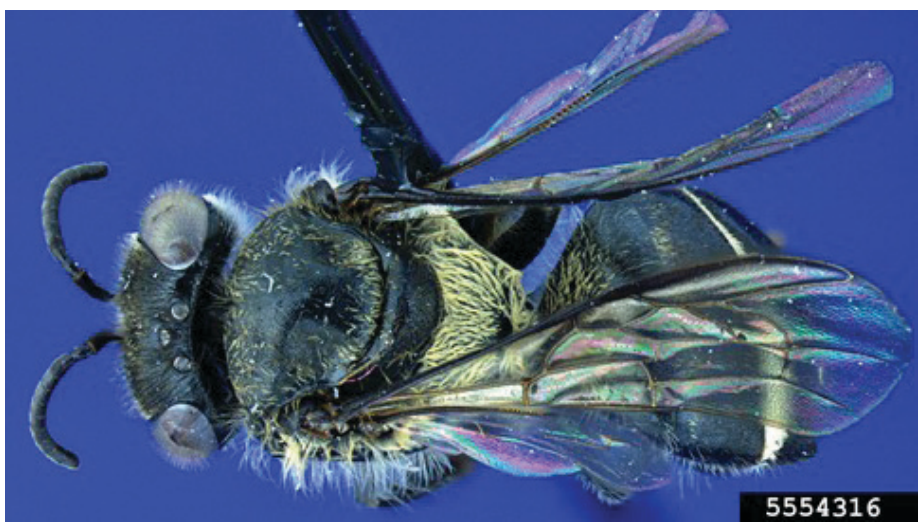

Figure 3. Image of female worker Apis andreniformis Smith. Note the yellow scutellum.

Credits: Allan Smith-Pardo, Exotic Bee ID, USDA APHIS PPQ, Bugwood. org

On Apis andreniformis drones, the basitarsus (the segment immediately after the tibia) of the hind leg has a hook-like extension. It is hypothesized that this extension grasps onto the queen's hind leg during mating (Ruttner 1975). The extension is shorter in Apis andreniformis in comparison to Apis florea (Figure 5). Other morphological differences between the two sister species include the wing venation.

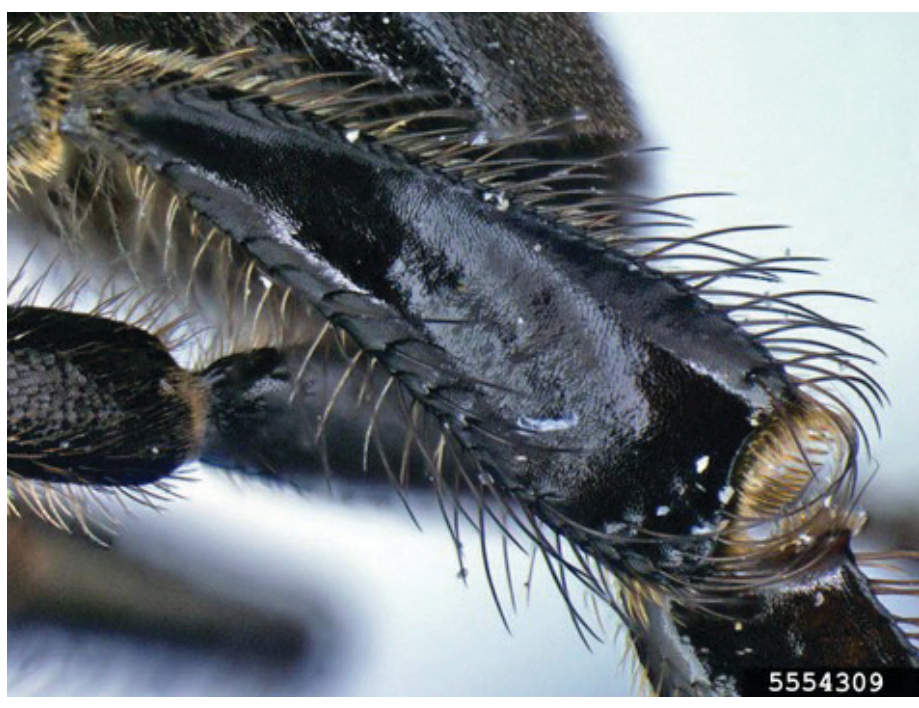

Figure 4. Side view of hind leg of Apis andreniformis Smith female worker bee depicting black hairs.

Credits: Allan Smith-Pardo, Exotic Bee ID, USDA APHIS PPQ, Bugwood. org

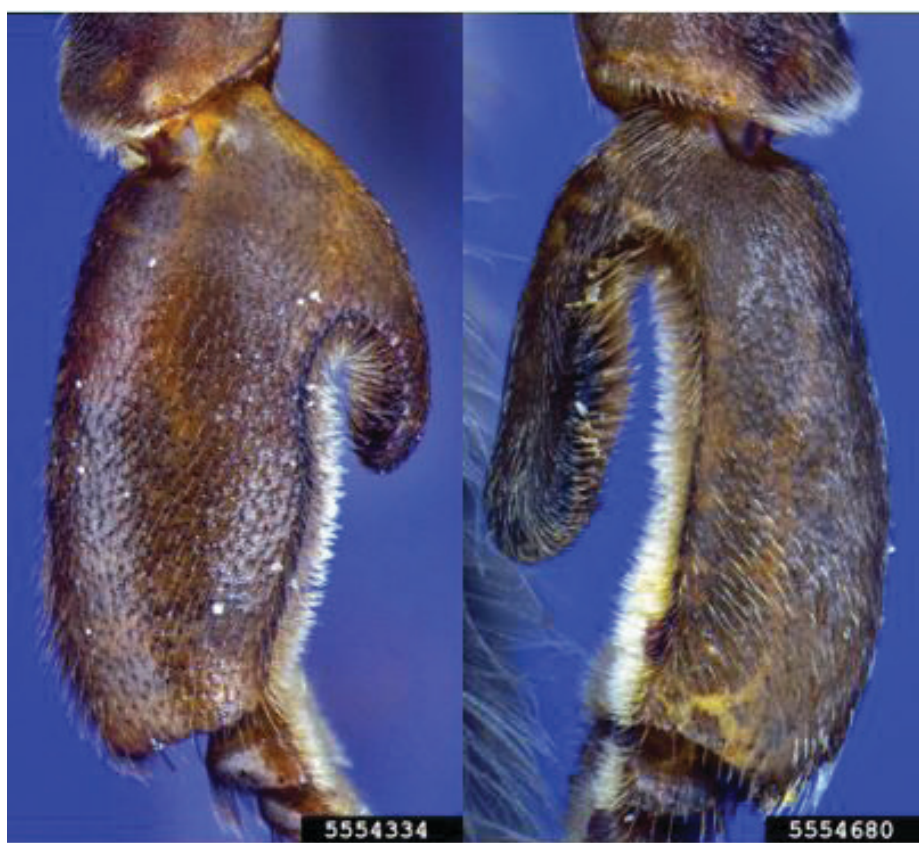

Figure 5. Comparison of hind basitarsus of Apis andreniformis Smith drone on left and Apis florea Fabricius drone on right. Note the shorter hook-like extension on Apis andreniformis Smith on the left. Credits: Allan Smith-Pardo, Exotic Bee ID, USDA APHIS PPQ, Bugwood. org

\section{Biology}

Apis andreniformis has four distinct life stages which include egg, larva, pupa, and adult. Members of the colony include drones, female workers, and a queen. The queen is identified by her large entirely black abdomen (Wongsiri et al. 1996). After mating with 10 to 20 drones (Oldroyd 1997), the queen returns to the nest and lays individual eggs in six-sided cells. The larva emerges from the egg and develops into a drone, female worker bee, or queen. 
Nourishment received from the worker bees determines which larvae will develop into queens.

Apis andreniformis builds a single comb nest on a twig (Figure 6) in shaded forests near creeks. It is an exposed nest with a single vertical comb, often connected to a bamboo, banana, coffee, tea tree or other small shrub twig by plant resin (Wongsiri et al 1996). The resin serves as a source of attachment and a deterrent to predators, especially weaver ants (Oecophylla smaragdina) (Fuchs and Tautz 2011).

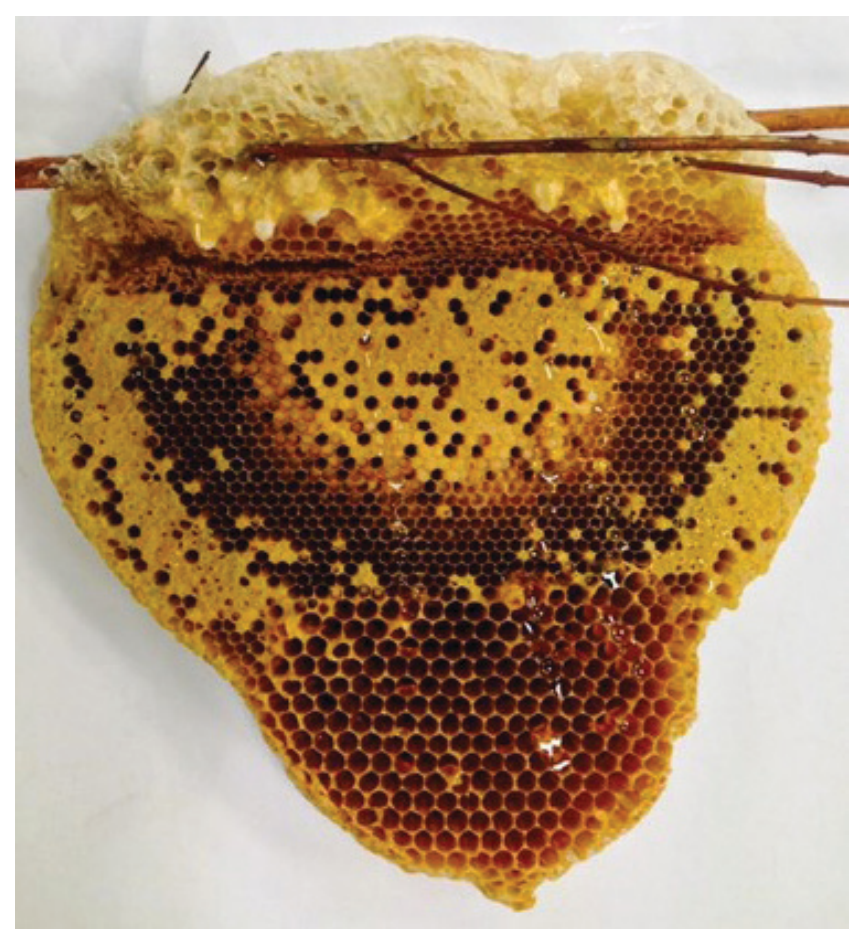

Figure 6. Black dwarf honey bee, Apis andreniformis, Smith nest. Credits: John S. Ascher via discoverlife.org (https://www.discoverlife. org $/ \mathrm{mp} / 20$ p?see=I_JSA4496\&res=640\&flags=subgenus)

The parasitic mite Euvarroa wongsirii is unique to Apis andreniformis (Lekprayoon and Tangkanasing 2009). The mite breeds within the drone brood cells of this honey bee species. Due to the limited breeding season of this mite and hygienic behavior of Apis andreniformis, the mite does not appear to be detrimental to the colony's overall health (Warrit and Lekprayoon 2011).

Unlike other honey bee species, there is little kinship recognition among Apis andreniformis. It is not uncommon in a queenless Apis andreniformis colony for workers to abscond and merge with a queenright Apis florea colony. This is to the species' detriment due to the successful egg policing behavior of Apis florea and the destruction of developing Apis andreniformis eggs (Wongvilas et al. 2010).

Another feature that separates the black dwarf honey bee from other honey bees outside of its subgenus is the orientation of the waggle dance, a method bees use to communicate location of resources. The large honey bee species and the cavity nesting honey bees all share the location of a resource with a vertical waggle dance influenced by gravity and the position of the sun. In contrast, Apis andreniformis dances on the horizontal surface of the uppermost part of the nest and indicates resources as a straight line to the source (Raffiudin and Crozier 2007).

\section{Economic Impact}

In Southeast Asia, Apis andreniformis are vital pollinators because the area lacks commercial pollination (Rattanawannee and Chanchao 2011). Apis andreniformis has been identified visiting over 34 plant species including the leopard lily (Figure 7), mango and key lime trees, Rusty Pittosporum, Simpleleaf Chastetree, Chinese violet as well as many others (BOS 2020).

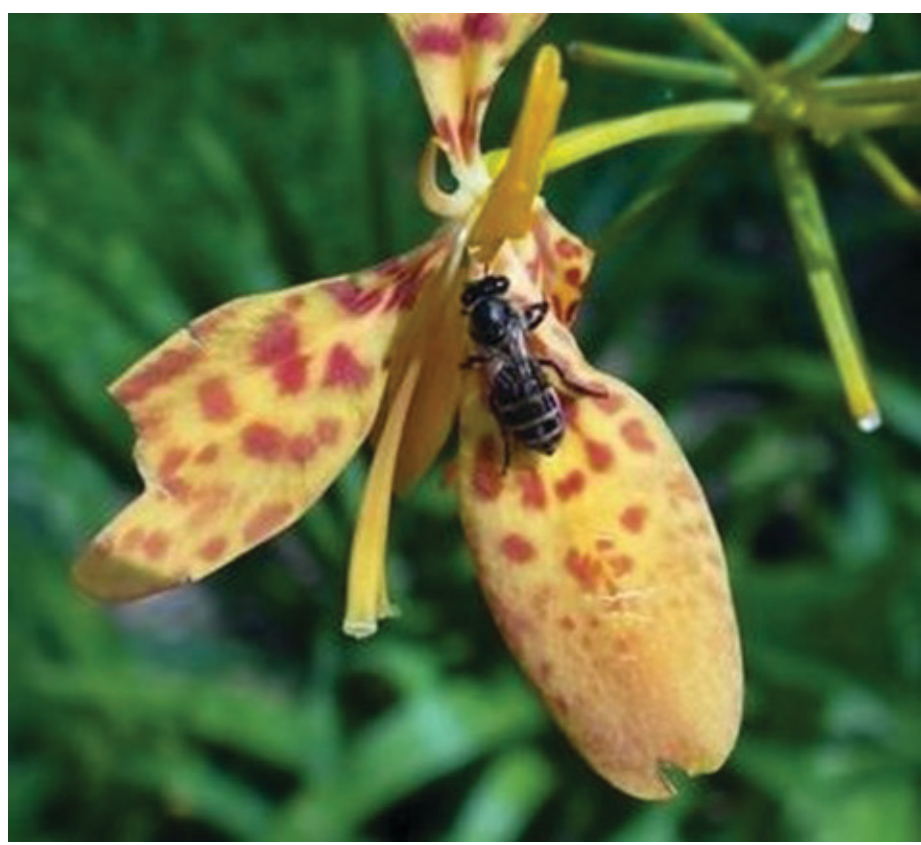

Figure 7. Worker female Apis andreniformis Smith feeding on nectar from a leopard lily (Iris domestica).

Credits: John S. Ascher via discoverlife.org. https://www.discoverlife. org $/ \mathrm{mp} / 20 \mathrm{p}$ ?see=I_JSA3201\&res=640\&flags=subgenus

In comparison to other Asian honey bee species, Apis andreniformis creates the smallest nests and produces the least amount of honey. Despite this, honey, pollen, royal jelly, wax, and bee venom are products that can be sourced from the nests of Apis andreniformis. However, the economic value is not evident in the literature (Wongsiri et al 1996). Chen et al. (1998) describe the selling of entire Apis florea nests for food in markets in Thailand with an average sale of 10 nests per stand per day. It could be inferred that nests of Apis andreniformis are sold as well due to frequent confusion between the two species. Oldroyd and Nanork (2009) verify that honey hunting of Apis andreniformis colonies is a reality. During honey hunting of dwarf honey 
bees the hunter simply shakes the honey bees off of their single comb nest. Then the entire nest is removed from the twig or branch, requiring fleeing bees to reconstruct new nests.

\section{Management}

There are sparse reports of successful management of Apis andreniformis colonies using modern beekeeping practices. Relocation of colonies of this honey bee has been unsuccessful as they generally swarm away from the area of relocation (Gupta 2014).

Deforestation and honey hunting in Southeast Asia may lead to local extinction of Apis andreniformis colonies (Oldroyd and Nanork 2009). Management of Apis andreniformis should include conservation strategies aimed at protecting forests, the nesting areas of this honey bee. Further interventions should emphasize responsible honey harvesting methods.

While Apis andreniformis is not currently found in North America, nor is there evidence to suggest that this bee might become an invasive species in the U.S., its presence is still monitored by the Florida Department of Agriculture and Consumer Services Apiary Inspection service.

\section{Selected References}

Biodiversity of Singapore. (2020). Apis (Micrapis) andreniformis Smith, 1858. https://singapore.biodiversity.online/ species/A-Arth-Hexa-Hymenoptera-000006

Chen, P. P., S. Wongsiri, T. Jamyanya, T. E. Rinderer, S. Vongsamanode, M. Matsuka, H. A. Sylvester, and B. P. Oldroyd. 1998. "Honey bees and other edible insects used as human food in Thailand." American Entomologist 44: 24-29.

Discover Life. (2020). Apis andreniformis Smith,1858. http:// idtools.org/id/bees/exotic/factsheet.php? name $=16742$

Discover Life. (June 2020)

Exotic Bee ID. 2018. Black dwarf honey bee (Apis andreniformis) Smith. https://www.invasive.org/search/action. cfm? $\mathrm{q}=$ apis+andreniformis+ Invasive.org. (June 2020)

Fuchs, S., and J. Tautz. 2011. Colony Defence and Natural Enemies. In: Hepburn H, Radloff S. Honeybees of Asia. Springer Netherlands. Heidelberg, DE. pp 369-395.
Hepburn, H. R., and R. E. Radloff. 2011. "Biogeography of the dwarf honeybees, Apis andreniformis and Apis florea." Apidologie 42: 293-300.

Hui, T. H. 2014. A hive of black dwarf honeybees at Kent Ridge campus. Singapore Biodiversity Records, National University of Singapore. https://lkcnhm.nus.edu.sg/app/ uploads/2017/04/sbr2014-101-102.pdf. (July 2020)

ITIS. 2017. Apis andreniformis Smith, 1858 Taxonomic Serial No.:763550. The Integrated Taxonomic Information System. (June 2020)

Lekprayoon, C., and P. Tangkanasing. 1991. "Euvarroa wongsirii, a new species of bee mite from Thailand." International Journal of Acarology 17: 255-258.

Oldroyd, B. P., M. J. Clifton, S. Wongsiri, T. E. Rinderer, H. A. Sylvester, and R. H. Crozier. 1997. Polyandry in the genus Apis, particularly Apis andreniformis. Behavioral Ecology and Sociobiology 40(1): 17-26.

Oldroyd, B. P., and P. Nanork. 2009. "Conservation of Asian honey bees." Apidologie 40: 296-312.

Raffiudin, R., and R. H. Crozier. 2007. "Phylogenetic analysis of honey bee behavioral evolution." Molecular Phylogenetics and Evolution 43: 543-552.

Rattanawannee, A., and C. Chanchao. 2011. Changing Diversity in Changing Environment: Bee Diversity in Thailand and the Applications of Bee Products. O Grillo and G Venora. InTech, Rijeka. 133-162 pp.

Rattanawannee, A., C. Chanchao, and S. Wongsiri. 2007. "Morphometric and genetic variation of small dwarf honeybees Apis andreniformis Smith, 1858 in Thailand." Insect Science 4: 451-460.

Rinderer, T. E., S. Wongsiri, B. Kuang, J. Liu, B. P. Oldroyd, H. A. Sylvester, and L. I. de Guzman. 1996. "Comparative nest architecture of the dwarf honey bees." Journal of Apicultural Research 35: 19-26.

Rinderer, T. E., B. P. Oldroyd, S. Wongsiri, H. A. Sylvester, L. I. de Guzman, J. A. Stelzer, and R. M. Riggio. 1995. “A morphological comparison of the dwarf honey bees of southeastern Thailand and Palawan, Phillipines." Apidologie 26: 387-394. 
Rinderer, T. E., B. P. Oldroyd, S. Wongsiri, H. A. Sylvester, L. I. de Guzman, S. Potichot, W. S. Sheppard, and S. L.

Buchmann. 1993. "Time of drone flight in four honey bee species in south-eastern Thailand." Journal of Apicultural Research 32: 27-33.

Ruttner, F. 1975. "Ein metatarsaler Haftapparat bei den Drohnen der Gattung Apis (Hymenoptera: Apidae)." Entomologia Germanica 2: 22-29.

Smith, F. 1858. "Catalogue of the hymenopterous insects collected at Sarawak, Borneo; Mount Ophir, Malacca; and at Singapore, by A R Wallace." Proceedings of the Linnaean Society of London 2: 42-130.

Warrit, N., and C. Lekprayoon. 2011. Asian Honeybee Mites. In: Hepburn H, Radloff S. Honeybees of Asia. Springer Netherlands. Heidelberg, DE. pp 347-368.

Wongsiri, S., K. Limbipichai, P. Tangkanasing, M. Mardan, T. Rinderer, H. A. Sylvester, G. Koeniger, and G. W. Otis. 1900. "Evidence of reproductive isolation confirms that Apis andreniformis (Smith, 1858) is a separate species from sympatric Apis florea (Fabricius, 1787)." Apidologie 21:

47-52.

Wongsiri, S., C. Lekprayoon, R. Thapa, K. Thirakupt, T. E. Rinderer, H. A. Sylvester, B. P. Oldroyd, and U. Booncham. 1996. "Comparative biology of Apis andreniformis and Apis florea in Thailand." Bee World 77 (4): 23-35.

Wongvilas, S., S. Deowanish, J. Lim, V. R. D. Xie, O. W. Griffith, and B. P. Oldroyd. 2010. "Interspecific and conspecific colony mergers in the dwarf honey bees Apis andreniformis and A. florea." Insectes Sociaux 57: 251-255.

Wu, Y. R., and B. Kuang. 1986. "A study of the genus Micrapis (Apidae).” Zoological Research 7: 99-102 (in Chinese).

Wu, Y. R., and B. Kuang. 1987. "Two species of small honeybee- a study of the genus Micrapis." Bee World 68: 153--155. 